\section{Galvanic Body-sway Test の診断的意義}

○田中宗昭, 本庶正一, 小林淑子, 嶋本加寿子, 兼 定啓子（山口大）

Galvanic 刺激に上り誘発される身体動摇を詳細に観 察記録解析することにより，病栄局在部位の確定と疾患 の鑑别を行うことを目的とする。

方法：Galvanic 刺激により誘発される身体動摇を頭

\section{0 小脳失調症に於ける重心動摇記録}

\section{Granigoniometry test(G.G.T.) を含めて}

渡辺 勈○大久保仁, 小高修司, 堤内邦彦(東医菌大)

重心動摇計の発達により種々な涘㭧飞対するパターン や周波数分析が行なわれ特徽する所見が得られている。 吾々は重心動摇計に斜面台检查の目荷を加え，上り平衡 維持の機棈を明らかにすへく考え，第34回平衡神経科学

\section{1 圧变化性前庭反応の実験的研究}

○調 重昭, 曾田豊二, 池田 公, 加藤寿彦, 松尾正彦 (福岡大)

炎症をはじめ中耳要因の内耳波及は今迄にも随分と諭 じられ，外耳・中耳の気生变化が眼振中平衡機能飞影響 を及ほすことす散発的ではあるが報告がなされている。 われかれは僈性中耳炎には真珠腫飞限らず王迫眼振検查

\section{2 瘦孔症候の臨床}

○本鷹正一, 関谷 透, 田中宗昭, 三谷啺広（山口 大)

臨床上，瘦孔症侯は慢性中耳炎，とくに耳真珠腫の症 例に蛙こり易く，さらにその術後に発症することがある ことは周知の事実である。これ関する臨床的検討はす
部に装著した加速度計で検出し，医用電子計算機を用い て加算平均した後，その波形を解析した。特飞刺激開始 及び終了後における，身体動摇開始までの潜時，動嵒開 始後最高㣂位まで所要時間, 通電中の偏位を示標とし て解析した。

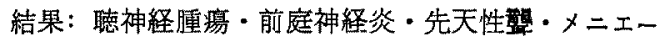
ル病等の症例化つき比較検討した結果, 神経伝尊路の障 害例では身体動摇の発現は悪く，内耳障害例では比較的 良く誘発される所見を得た。

会では正常人の傾斜目荷の特微を報告した。今回これを もとに小脳失調患者 33 名のデーターを比較榆討した。小 脳失調患者は立位では踵からの重心位置が（足長比）が 常人平均 $47 \%$ K比L $60 \%$ 前後と前傾荷重の傾向があり，

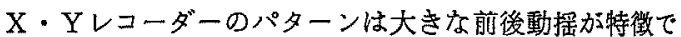
ある。これは時田も述べている。また閉眼時動摇面積が 正常比より著明に大であり，息こらえで面積は縮少す る。さらに疾患による特徴や斜面負荷についての知見を 述ベ。

を施行しているが，今回はメマイ患者と正常者の王迫眼 振を㿝倹討したので所謂 Fistel-Symptome の再検討と いらことでとめた。

今後, 人類は地上の平常状態とは環境の異なる染間で あ適合していかねばならぬ機会が多くなると思われる。 それで臨床実験的に正常者や䠦床例に正曾荷を行った際 の重心動擉計波形のコンピュータ分析を試み, 気任变化 性の平衡失調を量的保把握した。メマイ患者真荷検査と しての平衡生理上の意義を考察した。

で古くより諸家によって行われているが，なお今日多 くの問題点がある。

吾々は山口大学耳餅科で最近経験した35例の本症の臨 床像を観察し，1. 㢞孔症候の型。2.手術による迷路骨色 の瘟孔の有無とその局在。3. 手術所見。4. 瘦孔の処置飞 対する検討。5.術後の経過飞ついて，報告する。

\section{>第 24 群}

83 小脳橋角部疾患の聴覚平衡障害に関する研究

坂本伸一郎, ○鈴木史人, 斉藤久樹, 具柄孝一, 平 岡真理子(弘前大)

後頭蓋畕, 特飞小脳橋角部はその解剖学的見地から, 聴賞及び平衡機能に密接な関連性を有する。従ってこの 部位の種々の疾患に上って, 多種多様の聴覚障害や平衡 機能障害が出現し，その主な疾患として聴神経連瘍があ

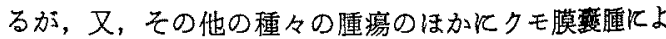

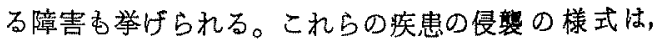

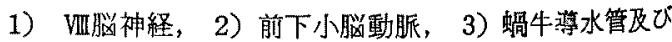
内耳孔を介しての内耳外リンパヘの交流，4）延䯣の聴 党，前庭中枢路などへの影響を考慮しなければならな い。今回演者らは，開頭手術により病因とその所在を礁 認出来大小脳橋角部疾患例のう方，経過を follow up 出 来た18症例を挙げ，その症状の出現や検査成綪から考察 を加えた。 